\title{
Problematic Yet Needed: Shifting Problematisations of Migrant Reception in Malmö 1945-1970
}

\author{
Pål Brunnström \\ Institute for studies in Malmö's history, Malmö University, Malmö, Sweden \\ Robert Nilsson Mohammadi \\ Department of society, culture and identity, Malmö University, Malmö, Sweden
}

\begin{abstract}
This article describes and analyses by whom, in what ways and with what consequences migrant reception was performed in Malmö during the period $1945^{-1970}$ and how this changed over time. Inspired by Carol Bacchi's 'what's the problem represented to be' (WPR) approach, the article analyses the shifting problematisations of migrant reception in Malmö, and argues that there were two decisive shifts in Malmö's migrant reception policy. With the help of Robert Miles' concept of racialisation, the article shows that different migrant groups were racialised in different ways, depending on how they were depicted by the Swedish society. We also identify a gendered racialisation as women and men were racialised differently.
\end{abstract}

\section{Keywords}

migration - urban history - racialisation - postwar Europe

\section{Introduction}

Going through rapid industrialisation and urbanisation at the turn of the twentieth century, Sweden changed from an emigration country, with a quarter of its population leaving for the US between 1875 and 1930, to an immigrant-receiving country in the years after the Second World War. ${ }^{1}$ In Swedish

1 Statistiska centralbyrån, Befolkningsutvecklingen i Sverige under 250 år. Historisk statistik för Sverige (Stockholm 1999) 13 o. 
historiography, the period $1945^{-1970}$ has been referred to as 'the quartercentury of labour migration', a period during which the number of foreign-born residents in Sweden tripled. ${ }^{2}$ During this period, when a large number of refugees and labour migrants arrived, migration policy and migrant reception policy underwent several decisive shifts. While Swedish migration policy on the national level is researched to some extent, we know less about how migrant reception was organised. This is partly because of a lack of such policy on the national level for the first part of the period, but also because migrant reception often was (and is) organised at the local or city level. Hence, research on migrant reception policy and practice from a city perspective is an important undertaking. As will be shown in this article, the relationship between the national and the city level is not one-directional but influences run in both directions.

In this study, we look at the city of Malmö, a mid-sized city on the southern border with neighbouring Denmark. With only the narrow strait of Öresund separating it from Denmark, Malmö has a long history of migration. However, as it was for the rest of Sweden, net immigration was low until after the Second World War. Since Malmö and Sweden were both unaffected by the war, the city had a flying start during the post-war boom and received both labour migrants and refugees after the war. The purpose of this article is to describe and analyse by whom, in what ways and with what consequences migrant reception was performed in Malmö during the period 1945-1970 and how this changed during this time.

Looking at the statistics of foreign citizens living in Malmö, it is evident that there was sharp increase directly after the war, and again during the 196os, which helped spur (as will be demonstrated in this article) a change in the municipal migrant reception policy after 1965 . Hence, we identify two major shifts in the problematisation of migrant reception in Malmö, which give rise to

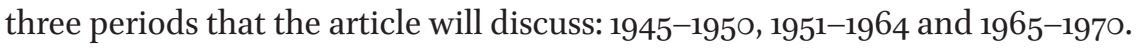

2 M. Byström and P. Frohnert, Invandringens historia. Från 'Folkhemmet' till dagens Sverige (Stockholm 2017) 33-53. 
Foreign citizens living in Malmö 1910-19703

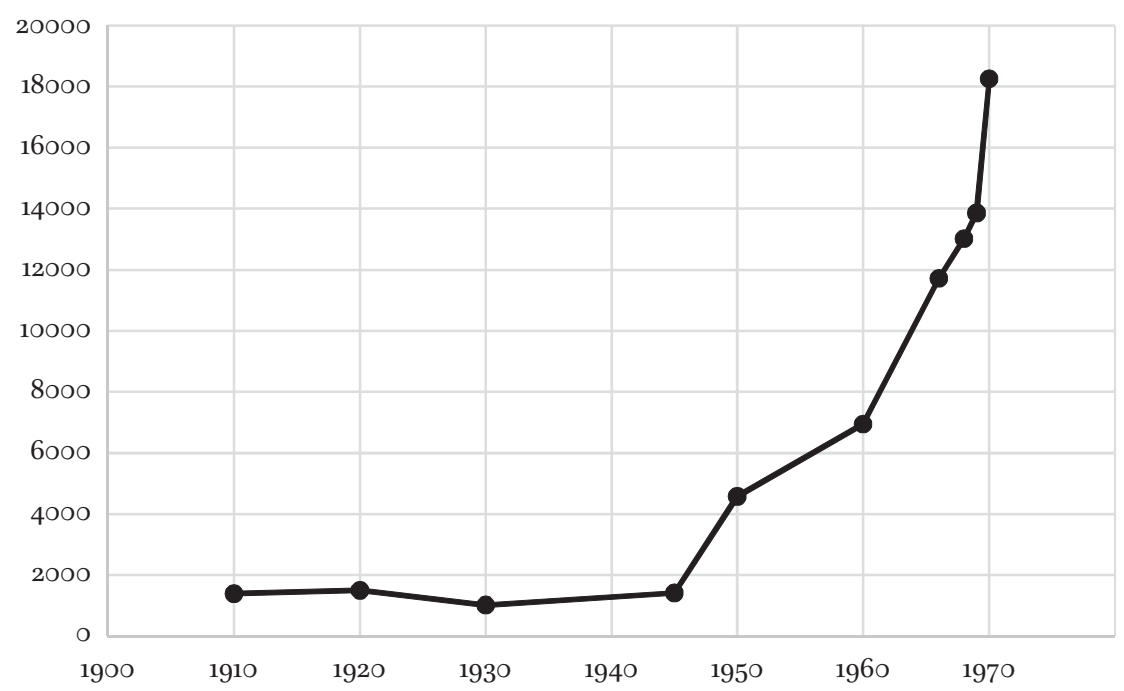

In the first shift, the industries in Malmö were trying to manage a lack of labour by recruiting refugees and foreign workers. As the 'problem' at hand was the lack of labour and the arrival of migrants was seen as a solution, the companies were charged with organising migrant reception focusing on basic needs such as housing. The municipality largely remained inactive. In the second shift in the late 196os, the main focus of migrant reception changed from supplementing basic needs to a broader project of societal inclusion of migrants, coinciding with a more general shift in municipal responsibility and ability of providing welfare services to its citizens. As Sweden was being governed by Social Democratic-led governments from 1932 to 1976 , discussions on the inclusion of migrants into the welfare system were key in migrant reception, and this was especially true in Malmö, in many ways the cradle for Swedish Social Democratic labour movement.

Consistent with European research on migration, Swedish historiography emphasises the national level. However, in the Swedish case a striking feature is that, as Mikael Byström and Pär Frohnert conclude, there is a general lack

3 H. Swedner, Invandrare i Malmö: Forskningsrapport från Invandrarutredningen (Stockholm 1973) $33,51$. 
of historical research on migration and migrants for the period 1945-1970. ${ }^{4}$ They identify two different migration regimes for the period: firstly, 1933-1945 when Sweden received minor influxes of Jews and other refugees fleeing Nazi Germany, as well as major waves of refugees arriving from the Nordic countries during the latter part of the war. The second period $1945^{-1972}$ was dominated by labour migrants coming to Sweden, during an era of open borders and economic boom. Nordic migrants dominated, but also workers from southern Europe arrived.

However, some research on the period exists, mostly emphasising the period after 1965 when policy on migrant reception took a more active turn, but generally ignoring the period $1945-1965 .{ }^{5}$ Christina Johansson analyses discourses on migration and migrants from the mid-196os to late 199os. Emphasising the role of the government, Johansson also discusses national actors such as trade unions and identifies important shifts and ruptures in the Swedish discourse on migration during the period. ${ }^{6}$ Other researchers emphasise the role of trade unions and employers organisations in influencing state policy on labour migration. ${ }^{7}$ Economic historian Joacim Waara identifies labour migration as a highly conflictual policy field, as employers organisations had a strong interest in increased labour supplies and hence labour migration, while trade unions had an interest in limiting competition that could lower wages despite their broader interest in promoting economic development. ${ }^{8}$ In Malmö, employers were important actors in local migrant reception in the absence of policy and praxis from the local and national government in the period $1945^{-1965}$.

Focusing on other Swedish cities, there is an emerging field investigating migrant experiences, notably through oral history but also using other

4 Byström and Frohnert, Invandringens historia.

5 T. Hammar (ed.), European immigration policy. A comparative study (Cambridge 1985); L.-E. Hansen, Jämlikhet och valfrihet. En studie av den svenska invandrarpolitikens framväxt (Stockholm 2001); C. Dahlström, Nästan välkomna. Invandrarpolitikens retorik och praktik (Göteborg 2004); U. Mörkenstam, 'Ekonomi, kultur och jämlikhet. Teman i svensk politik i invandrarfrågor decennierna efter andra världskriget', Historisk tidskrift för Finland 95 (2010) 572-607; K. Borevi, 'Sverige. Mångkulturalismens flaggskepp i Norden', in G. Brochmann and A. Hagelund (eds.), Velferdens grenser. Innvandringspolitikk og velferdsstat i Skandinavia 1945-2010 (Oslo 2010) 41-130.

6 C. Johansson, Välkomna till Sverige. Svenska migrationspolitiska diskurser under 19oo-talets andra hälft (Malmö 2005).

7 D. Frank, Staten, företagen och arbetskraftsinvandringen. En studie av invandringspolitiken $i$ Sverige och rekryteringen av utländska arbetare 1960-1972 (Växjö 2005); J. Johansson, 'Så gör vi inte här i Sverige. Vi brukar göra så här.' Retorik och praktik i LO:s invandrarpolitik 1945-1981 (Växjö 2008).

8 J. Waara, Svenska arbetsgivareföreningen och arbetskraftsinvandringen 1945-1972 (Göteborg 2012). 
sources. ${ }^{9}$ With Malmö as one example among others, sociologist Anna-Maria Sarstrand Marekovic explores the establishment of Immigrant Service institutions in Swedish cities in the mid-196os, tracing important actors in their creation and their subsequent institutionalisation and development up to the present. ${ }^{10}$ With the exception of her work, recent academic research on Malmö for the period $1945^{-1970}$ is lacking.

Malmö can be assumed to be typical of medium-sized Swedish cities of the period as it shared key features with many other Swedish cities of the era. The labour market was dominated by large industries, the availability of housing was severely strained because of the rapid urbanisation process in the pre-wwiI period and the population was dominated by working class people of predominantly Swedish origin. However, Malmö also stands out in some respects. It was uniquely dominated by the Social Democratic labour movement and its affiliated organisations, and in many cases, it was a testing ground for Social Democratic policy that was later implemented nationwide. In relation to migration, it also showed some distinguishing features. In 1947, the Malmö based company KMV was among the first to undertake international recruitment, and in 1967, Malmö was the first city to investigate the situation of its immigrants. Malmö was also among the first Swedish cities to institutionalise an office such as the Immigrant Service. Hence, Malmö is both typical and a special case.

What we intend to show in the following, apart from how migrant reception has changed over time in Malmö in two decisive shifts, is how Malmö's development of knowledge, policy and practice became incorporated into national policy-making. This brings to the fore the importance of studying the local level and the interconnectivity between different policy levels, challenging the idea of migrant reception policy being created top-down (or at least indicating the possibility of other processes). We will also argue for the fruitfulness of the concept of 'racialisation' for a nuanced understanding of the processes of migrant reception. This terminology is discussed in the next section, which describes the theoretical and methodological frame for the article.

9 M. Jaakkola, Den etniska mobiliseringen av sverigefinnarna (Stockholm 1989); J. Kuosmanen, Finnkampen. En studie av finska mäns liv och sociala karriärer i Sverige (Hedemora 2001); M. Ågren, 'Är du finsk, eller?' En etnologisk studie om att växa upp och leva med finsk bakgrund i Sverige (Göteborg 2006); E. Strollo, Det städade folkhemmet. Tyskfödda hembiträden i efterkrigstidens Sverige, Göteborg (Göteborg 2013); J. Svanberg, Migrationens kontraster. Arbetsmarknadsrelationer, Schleswig-Holstein-aktionen och tyskorna vid Algots i Borås under 1950-talet (Lund 2016).

10 A. S. Marekovic, Från invandrarbyrå till flyktingmottagning. Fyrtio års arbete med invandrare och flyktingar på kommunal nivå (Lund, 2011). 


\section{Theoretical and Methodological Frame}

A methodological problem for our inquiry is that for the better part of the period, 'migrant reception' was not necessarily what the historical actors thought they were engaged in. We have found Carol Bacchi's 'what's the problem represented to be' (WPR) approach to be a useful way of mediating between our conceptual framework and the different frameworks of the actors, and also for discerning consecutive policies for migrant reception. ${ }^{11}$ The WPR approach assumes that we are governed through problematisations and that policies are formulated as responses to perceived problems. Policies are often seen as reactions to different issues, but the WPR approach stresses that the issue at hand needs to be understood as a problem before an intervention can be suggested. The process of problematisation results in specific representations of problems, which reduce complex issues in order to make them make sense. Following the WPR approach, governing (governance) is analysed as a cultural (signifying) practice, and problematisations as cultural products. What needs to be understood is how socially established and culturally available meanings go into the shaping of problematisations. ${ }^{12}$

Central to our understanding the problematisation of migrant reception in Malmö is the concept 'racialisation' as developed by Robert Miles. ${ }^{13}$ With this concept, Miles and other scholars of that tradition describe ethnicity and 'race' as socially created categories, constructed to divide people on the basis of attributed traits, often focusing on appearance and descent, but the tradition emphasises that almost any trait can be used to create distinction, and they exemplify this with accent, name, occupation, behaviour, place of residence and means of subsistence. ${ }^{14}$ Hence, racialisation is a process that happens to the migrant in the country of reception and can vary from country to country and change over time. ${ }^{15}$

\footnotetext{
11 C. L. Bacchi, Analysing policy. What's the problem represented to be? (Frenchs Forest 2009).

12 Bacchi, Analysing policy.

13 R. Miles, Racism (London 1989).

14 R. Barot and J. Bird 'Racialization. The genealogy and critique of a concept', Ethnic and Racial Studies 24 (2001) 601-618; P. H. Collins, Black feminist thought. Knowledge, consciousness, and the politics of empowerment (New York 2009); G. Lewis, 'Experiencing intersectionality and feminist displacements', Signs 38 (2013) 869-892.

15 S. Hall, 'Old and new identities, old and new ethnicities', in A. D. King, culture, globalization and the world system. Contemporary conditions for the representation of identity (Basingstoke 1991); A. Behtoui and S. Jonsson, 'Rasism—särskiljandets och rangordningens praktik', in: M. Dahlstedt and A. Neergaard (eds.), Migrationens och etnicitetens epok. Kritiska perspektiv $i$ etnicitets- och migrationsstudier (Stockholm 2013) 168-198.
} 
To investigate these problematisations and how migrants are racialised, we use sources such as political speeches and debates by elected politicians and municipal civil servants, documents related to policy implementation by municipal bureaucracies and the contributions of experts and professionals in the policy process - all of which are included in the materials expected to provide insights into the process of shaping a 'local policy arena', according to Tiziana Caponio, ${ }^{16}$ or the framing of a 'problem', in Bacchi's terms. Such materials have not been equally distributed among the actors or over the timespan that we are researching. Between 1965 and 1968, the municipality of Malmö worked out its own migrant reception policy and the sources are rich. Sociologist Kristina Belfrage's report Yugoslavs in Malmö, commissioned by Malmö's Social Services Department in 1967, is a key document explaining the municipality's process of shaping the arrival and reception of migrants into a problem that could be managed.

The problematisation behind the local industries' reception practices from 1945 onwards has not been as easy to trace. While migrant workers can be found in all the industrial branches present in Malmö, and also in domestic work, we have chosen to study Kockums mekaniska verkstäder (KMV) and the textile plant Manufakturaktiebolaget \& Malmö yllefabriks aktiebolag (MAB \& MYA) more closely. By this choice, we try to avoid the risk of reinforcing the imaginary of the migrant worker as a man, amply criticised by feminist scholarship and activism. ${ }^{17}$ Our choice is motivated by the fact that KMV's shipyard was the largest workplace in Malmö during the period examined, and that KMV (and MAB \& MYA, to some extent) was the local company with the most expanded apparatus for international recruitment and migrant reception, and also due to the accessibility of company archives. By using these sources as well as newspapers, documents from the municipal organisation and material from the trade unions, we can present consecutive representations of the problems that were operating in the local migrant reception in Malmö at different times, as well as how they were received and how they were resisted.

In the following, we will give a more extensive contextualisation of Malmö, before moving on to discussing the aforementioned periods of successive problematisations.

16 T. Caponio, 'Conclusion: Making sense of local migration policy arenas,' in: T. Caponio and M. Borkert (eds.), The local dimension of migration policymaking (Amsterdam 2010) 161-192.

17 W. Knokke, 'Kön, etnicitet och teknisk utveckling', in: C.-U. Schierup and S. Paulson (eds.), Arbetets etniska delning. Studier från en svensk bilfabrik (Stockholm 1994) 81-105; P. Ardalan (ed.), Women making herstory: 100 år av immigrantkvinnors liv och arbete i Malmö (Malmö 2016). 


\section{Malmö During the Quarter Century of Labour Migration}

During the period $1945^{-1970}$ a large number of migrants entered Sweden in successive waves from different countries of origin. Steps towards a common Nordic labour market had already been taken by the end of the Second World War, and this was institutionalised at the beginning of the 1950s. Following the praxis established by agreements with the Nordic countries, the Swedish borders were, de facto, open for migrants from other countries seeking employment from the early 1950s to the mid-196os. Labour migration was, however, monitored by the National Labour Market Board (AMS), and the national trade unions exercised a great influence on the allotment of work-permits. By regulating and controlling the migration, the labour migrants' right to equal pay and access to the same social security as domestic workers could be guaranteed. In the mid-196os, immigration increased at the same time that industry's demand for labour decreased. A growing number of labour migrants failed to acquire work and decent housing. At the same time, the national trade unions perceived a conflict between labour migration and women's entry into the workforce. The borders were gradually closed to migrants from outside of the Nordic countries from $1966 .^{18}$

The year 1945 marks a turning-point in Malmö's migration history since it was then that the numbers of labour migrants arriving in Malmö started to increase. Before the war, Malmö had been home to what has been called 'the old minorities', consisting mainly of Germans, Danes, a Jewish community and travelling as well as rooted Roma families, some of whom had been part of the city's population since medieval times. Immediately after the war, the local industry filled out their ranks of labourers with Danish workers. Between 1945 and 1970, Malmö received labour migrants from Denmark, Norway, Finland, Germany, Italy, Greece, Portugal, Iceland, Turkey and Yugoslavia, while those seeking refuge in Malmö included Eastern European Jews, Poles, Danes, Baltic people, Sudeten Germans, Hungarians, Czechs, Romani and a small number of American war deserters. The national origins of migrants to post-war Malmö were diverse, but their total numbers were initially low. The largest groups were people born in Denmark, Germany and Poland, and later, in the census of 1970, people from Finland and Yugoslavia. ${ }^{19}$

18 Byström and Frohnert, Invandringens historia, 39-42.

19 Folkräkningen den 31 december 1950 (Stockholm, 1952-1956); Folk- och bostadsräkningen 1970 (Stockholm, 1972); Swedner, Invandrare i Malmö, 7-8, 25, 31-66; K. Kern, Förrådd av öst och väst. Med rötterna i Böhmen: Från Prag till Malmö. Ett flyktingöde (Viken 1987); G. Zimmermann, Röster från ett krig. Brev och berättelser från andra världskrigets Tyskland (Västerås 2016). 
The migrants arriving in Malmö formed a socially heterogeneous group. Up until the mid-195os, the typical labour migrant arriving in Malmö was a young woman from Denmark or Germany seeking domestic work. Soon, work in the city's manufacturing industries became more prevalent. The labour market was gendered, with women working in textile and food industries, while men worked in the mechanical workshops and shipyards. In 1970, about one tenth of the city's population was foreign born. According to sociologist Harald Swedner, Malmö had by then acquired a reputation as a 'city of immigrants.' ${ }^{20}$

However, in 1945, the situation was very different, and what was perceived as the most pressing problem of that time (using Bacchi's WPR approach) was the lack of labour for the Malmö industries.

\section{Local Industry's Lack of Labour $1945^{-195^{\circ}}$}

In 1945, the production capacity of Swedish industries was left untouched by the Second World War, and Sweden in general and Malmö in particular had a flying start in the post-war economic boom. A perennial concern of the corporate board of the KMV was that its shipyard did not run at full capacity due to the lack of labour. Unable to find sufficient numbers of skilled workers-metalworkers and electricians were especially needed - consecutive board meetings in 1946 and 1947 noted delays in repairs and in the production of new military ships and commercial vessels. The evolving situation was supervised and amply evaluated by the company's engineers and personnel advisers, who, in their reports, perceived two interconnected problems in need of solving. First, it was not that workers were unavailable, but rather that workers with the required set of competencies were hard to find. The workers available in the region were either unskilled labourers or redundant construction workers. Both of these groups tended to work in the shipyard for only short lengths of time. In the case of the construction workers, this was explained by the fact that their field offered higher wages, while in the case of the unskilled labourers, it was explained by what was perceived as insufficient adaptability to the requirements of working in a modern shipyard. ${ }^{21}$ Hence, the 'problem' was the lack of the right kind of workers.

20 Swedner, Invandrare i Malmö, 7-9, 61; P.-M. Ristilammi, Rosengård och den svarta poesin. En studie av modern annorlundahet (Stockholm, 1994), 151-152.

21 Malmö city archives (Malmö stadsarkiv, MSA), Kockums mekaniska verkstad AB (KMV), Styrelseprotokoll 1945-1947. Authors' translation of all documents and articles in Swedish. 
To solve this problem, the shipyard began to make plans to recruit workers from war-torn Europe. This however, accentuated another problem identified by the KMV's corporate board, namely a housing shortage.

The biggest difficulty when it comes to acquiring new labour would be housing. A plan had been drawn up for the settlement of the housing issue during 1946-1947, which was presented. After discussion, the board decided to approve the purchase of 6 pcs. Barracks. ${ }^{22}$

This quote from the minutes of one of the board meetings in 1946 illustrates how important the housing issue was to the KMV. One of the solutions to the housing problem was to buy or build wooden barracks, and the company took over military barracks on the eastern and southern outskirts of the city, and also built barracks at the remote Klagshamn harbour. Solving the housing situation for its workers - and especially for workers with families who could not live in barracks - was seen as a way to solve the problem of labour shortages in the long-term. Thus, negotiations with state authorities, construction companies, property owners in the city and (albeit occasionally) the municipality were initiated. However, it proved hard to secure housing for families, sometimes due to national building quotas established during the war, and at other times due to unsuccessful negotiations with either the municipality or the building companies. Hence, many of the migrant workers were housed in barracks in peripheral areas of the city, with the company providing housing, food and at times, transportation to work (using special busses), and thereby taking an all-embracing approach to migrant reception. Through these efforts, the KMV's corporate board-perhaps inadvertently—created a local level of migrant reception, led by the local industry in negotiation, foremost, with state authorities, construction companies and property owners. The municipality was only involved in a marginal role as migration was seen as a response to the company's need for more labour and hence, as a problem for the company. This example illustrates the interconnectivity of different problems (the lack of housing and labour) and also how some actors, in this case the municipality, can define a cluster of issues as somebody else's problem.

The KMV started its international recruitments in 1946 by employing Danish workers, and it made numerous efforts to recruit skilled German workers (with only minor success). However, it was the recruitment of skilled metalworkers from northern Italy in 1947 that would make a lasting imprint on the migrant 
reception policy developed by the local industry. This collective recruitment was made by the KMV in collaboration with Beredningen för utländsk arbetskraft (BUA) and representatives of the Italian state. ${ }^{23}$ It was skilled workers who already had employment who were given the contracts, a selection that was in line with the corporate board's reasoning around the regional lack not only of skilled but also of conscientious and disciplined workers. Through the contract, the workers were promised a train ticket to Malmö, a minimum of two years employment at the KMV, food and housing in apartments. ${ }^{24}$ Judging by the minutes from the board meetings, the arrival of the workers from Italy was highly anticipated by the KMV's corporate board. The hopeful expectations however soon changed into disbelief as relationships with the migrant workers became strained, until they reached the point where the workers ventured into open conflict.

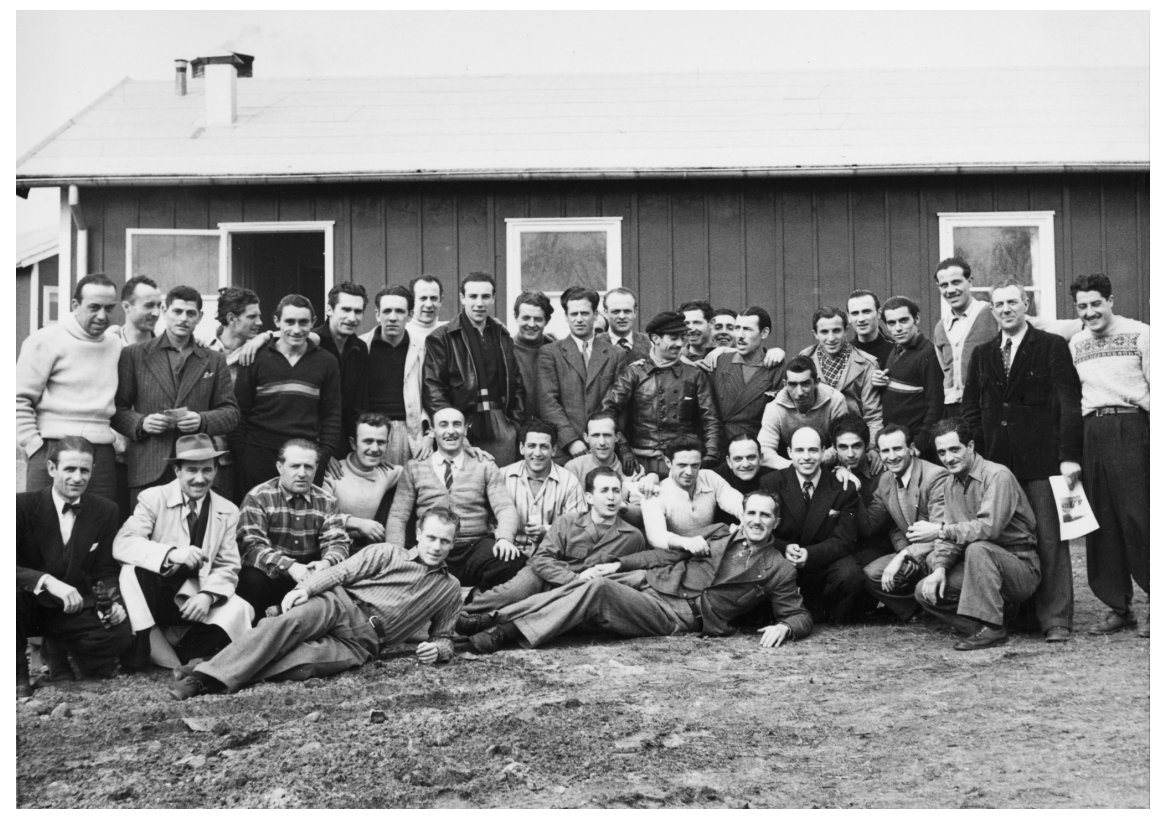

ILLUSTRATION 1 Italian workers standing in front of the wooden barracks in Bulltofta where they were offered housing upon arrival.

PHOTO: TT BILDBYRÅ

23 A. Tajani, När italienarna lovades guld och gröna skogar (Hörby 1999) 27-31; Waara, Svenska Arbetsgivareföreningen, 108; Byström and Frohnert, Invandringens historia, 37-38.

24 J. A. Lundin, Malmö Industristaden: Addo Cementa Ljungmans Kockums (Malmö 2007) 21. 
The first Italians arrived during the summer of 1947, after months of delays. However, conflict with the KMV erupted almost immediately. The Italian workers were dissatisfied with their salaries, with the housing and also with the food provided from the communal kitchens in the barracks. They contacted the Swedish trade union of metal workers, but their grievances were not acted upon. In March 1948, a majority of the Italian workers initiated a wild cat strike. The response from the KMV company was harsh, and they demanded that all workers should return to work before the end of the week or they would be sacked. The company administration wrote to the national employers' organisation to inform them of the situation and of the actions taken by the company. They described the Italians as having a different 'mentality' from Swedish workers and that they feared conflict between the workers:

We understand that the Italians have a different way of reacting than the Swedish workers, but we can no longer accept their undisciplined behaviour as it is making a very harmful impression on the Swedish workers. [...] Our departmental engineers fear that the Swedish workers soon will demand the removal of the Italian workers. ${ }^{25}$

To exemplify the 'mentality' of the Italian workers, a copy of an anonymous note claimed to have been delivered to the company administration was included in the letter. It read:

Your commands have a striking resemblance to the commands of the German occupation of Italy. The Italians used to tear up such proclamations, even at gunpoint from machine guns. ${ }^{26}$

What from the Italian workers may have been intended as a signal of moral firmness against perceived injustices was interpreted by the company as a sign of the different (in a negative sense) mentality of the Italian workers compared to that of the Swedish workers. Hence, a new problematisation was articulated, with a racialised stereotype of the Italians as lacking discipline and having a short-tempered affective disposition.

25 Arbetarrörelsens Arkiv i Skåne (AAS), Svenska Metallindustriarbetareförbundet Avd. 4 Malmö, Kockums Verkstadsklubb (SM4KMV), Letter from KMV to Sveriges Verkstadsförening 16 March 1948.

26 AAS, SM4KMV, Letter from KMV to Sveriges Verkstadsförening 16 March 1948, (note dated 11 March 1948). 


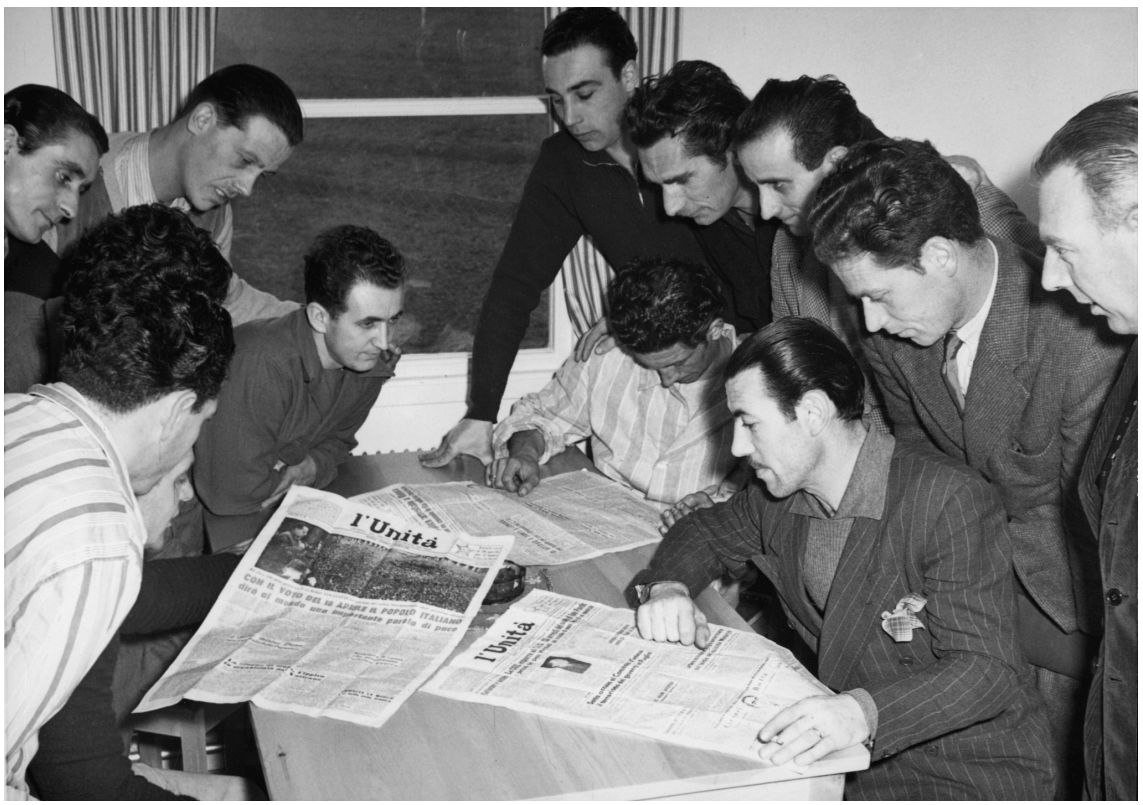

ILLUSTRATION 2 Italian workers during the strike, reading the Italian communist newspaper La Unitá.

PHOTO: TT BILDBYRÅ

The strike was partially successful as some of their demands were met, but a portion of the Italians chose to end their contracts and return to Italy, while some of them were sacked by KMV. A lasting legacy of the Italians' strike action in the memory of the KMV company board was that possible problems were associated with hiring workers from outside of Sweden, and especially Italians. Later, the recruitment efforts were focused on Germans, Sudeten Germans and Dutch workers. ${ }^{27}$ The solution to the problem of the perceived to be 'mentally different' Italians was to recruit from other countries.

Another example from the same period involves the Estonian war-refugees, mostly women, who were hired by the textile manufacturer MAB \& MYA in 1943. Only minor contingents of refugees were accepted into Sweden during and after the war, and Estonians were the largest group coming to Malmö. Upon arrival in Sweden (mostly on the island of Gotland), and after going through health check-ups, they were asked to choose if they wanted to work in forestry, fishing, agriculture or the textile industry. ${ }^{28}$ Hence, already upon

27 MSA, KMV, Styrelseprotokoll 1 February 1950.

28 A. Sarnäs and K. Sjöberg (eds.), På gränsen mellan krig och fred: Minnesbilder från Malmö 1939-1945 (Malmö 2015). 


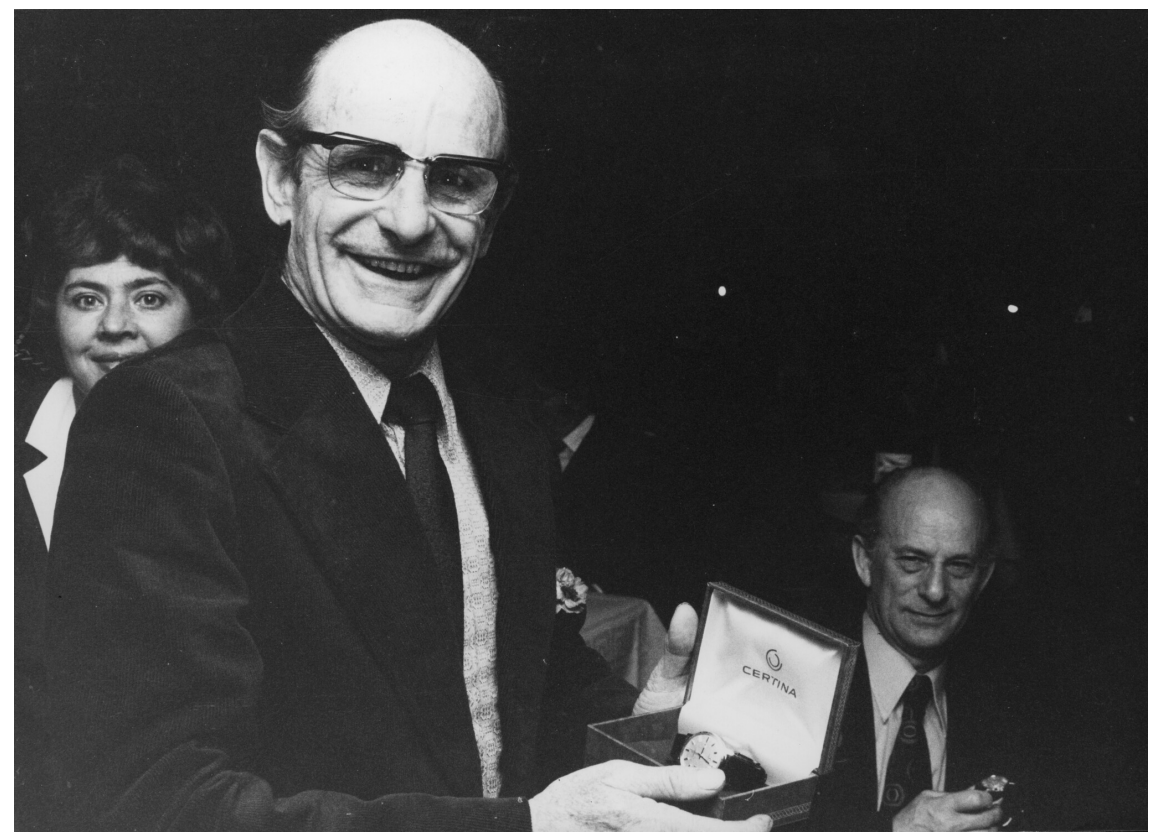

ILLUSTRATION 3 The Italian workers were hired on a two-year contract, but many of them stayed much longer.

Pictured is Bruno Benatti receiving a golden watch from Kockums shipyard after 25 years of service. РНоTO: MALMÖ CITY ARCHIVES.

arrival, their potential as labour was central to the Swedish authorities' reception of Estonian refugees.

Due to the long-standing lack of housing, the large textile factories had an existing infrastructure and were able to offer temporary housing to new employees in two guest houses located on the southern outskirts of Malmö near the factories. For the Estonian refugees, MAB \& MYA built wooden barracks in the same area. At the complex named Estgården, refugees were accommodated in simple housing with a common kitchen. ${ }^{29}$ In memories collected at a later date, one of the Estonian women recalled what it was like to be working at the textile plant:

in the store room [...] there was a really nice women named Märta who took care of me. She started drawing in the roof of store room; she drew

29 MSA, МАв осh MYA aktiebolag (МАв \& MYA), Handlingar rörande personalbostäder, FıA:3; Martin Andersson, 'Ljusa minnen från krigsåren', Sydsvenska Dagbladet (SDs) 23 October 2015, retrieved 16 March 2020; Sarnäs and Sjöberg, På gränsen mellan krig och fred, 125-130. 
a bird and said: 'En feogel' [a bird, in the accent of the Skåne region], so I learned the Skåne accent. It was at that place I learned the first words. Sometimes I went to her home, and her husband would teach me to write Swedish words, and I learned little by little. Most of the people working at MAв \& MYA were Swedish so I learned also from others. When we moved to Estgården, I lived with my parents in a room. Compared with what we came from it was paradise. We ate at the canteen in Estgården. ${ }^{30}$

The majority of the employees at the textile plant were women, and there were discussions between MAB \& MYA and the KMV about trying to recruit jointly, 'where the wife would take employment at МАВ \& MYA and the man at the workshop, and that the workshop would accommodate the family with housing. ${ }^{31}$ The gendered segmentation of the labour market was explicit and pronounced. The minutes and the actions of the companies give the impression that recruiting married workers was preferred.

Even though MАВ \& MYA and KMV preferred to hire married persons, this met obstacles due to the general lack of housing, so the companies created structures to accommodate single women and men in barracks. This was an existing practice for both companies when receiving Swedish workers who moved from places outside of Malmö. In the case of migrants, this also meant creating structures for migrant reception in a wider sense, as migrant life in the barracks also meant that the company assumed responsibility for organising food, transport to work (in the case of KMV) and organising childcare for the women with children working at МАВ \& MYA. The municipality abstained to a large extent from any involvement, and the workplace was the dominant sphere for migrant reception during the years immediately after the war. This also meant that little attention was given to the social and spatial inclusion of the migrants, and having the barracks placed in peripheral positions around the city meant that clusters of predominantly young people who did not speak Swedish were created. Some attention was paid to this by the local police who posted a guard at the barracks housing the Italians to prevent them bringing friends or women into the facilities. ${ }^{32}$

There are no indications that the Estonian refugees were treated as culturally different to Swedes. A form of racialisation discussed by Noel Ignatiev, ${ }^{33}$ among others, also happens when 'white' migrants are coded as such, and to

30 Sarnäs and Sjöberg, På gränsen mellan krig och fred, 125-126.

$31 \quad$ MSA, KMV, Styrelseprotokoll 23 August 1946, §107.

32 'Polisvakt avvisade flickor, Kockums italienare strejkar', Dagens Nyheter 16 March 1948.

33 N. Ignatiev, How the Irish became white (New York 1995). 
varying degrees, included in the national 'us' of the country of reception. Our interpretation is that the Estonian group was racialised as 'white' and perceived as similar to the Swedish population, a process facilitated by strong ties between Sweden and Estonia as the country was part of the Swedish kingdom in the 17th century and a popular resort for Swedish tourists. It could also be due to the different gender compositions of the migrant groups. The Italians were all male and the majority of the Estonian refugees were women. The police posting a guard at the barracks where the Italians lived reminds us of how those racialised as non-white often have been ascribed a form of masculinity that needs to be checked. ${ }^{34}$ The intersection of racialisation and gender gave rise to different problematisations and understandings of the respective migrant groups, and hence to different migrant reception attitudes to them.

The period $1945^{-5}$ o was characterised by the industry trying to solve its problem of a lack of labour by recruiting refugees and workers from other countries, and while doing so, encountering new problems such as finding housing for the migrants. As the perceived 'problem' was the lack of labour and the arrival of migrants was seen as a solution, the companies were charged with organising housing. Due to the housing shortage, this created a new problem, solved by renting and building wooden barracks to house the migrants. Since the barracks were not equipped with individual kitchens, this also meant that the companies shouldered the responsibility for food provision, and in the case of KMV (due to the peripheral location of the barracks), also transport. In this way, through a series of connected problematisations, the companies assumed an expanded responsibility for migrant reception and for the well-being of the migrants. The WPR approach helps us to suggest an explanation for this: pointing out how the problem was conceptualised also indicates why it was solved in a specific way. Since the lack of labour for industry was identified as the problem, the municipality found it easy to push the responsibility for finding housing, and other migrant reception issues, onto the companies. The Italians were racialised as 'mentally different' from Swedes and too radical, and thus turned into problems. In the following years, the lack of labour diminished and was less of a problem.

\section{Migrants Less Needed but Still the Industry's Problem 1951-1964}

Migration to Sweden continued in the 1950s, especially involving migrants from the Nordic countries after entering into agreement on a common labour

34 A. Davis (ed), Policing the black man: Arrest, prosecution, and imprisonment (New York 2017). 
market in 1953, but Malmö received only a minor portion of these migrants. The Government report of 1955 concluded that the baby boom of the 1940s, combined with increased activity by women in the labour market, would increase the number of workers, but the report still calculated ten thousand labour migrants arriving each year (an estimation fairly close to net migration during the period up to 1964 , at which point, it rose to twenty thousand). ${ }^{35}$ Net migration to Malmö halted at a total of three thousand during the period 1950-1963, but rose sharply in $1964 .{ }^{36}$ In the minutes of the boards of KMV and MAB \& MYA, the lack of labour was no longer described as a pressing problem, and issues regarding the practical details of organising migrant reception disappeared (with a few exceptions) from the minutes. Still, the municipality took very limited action to facilitate migrant reception, as migrants still were considered solutions to the 'problem' of lack of labour and hence were the industry's responsibility.

During this period, the majority of migrants were from Denmark and Germany, but there were also some Hungarian refugees who came to Malmö during the crisis of 1956 (when the Soviet Union invaded their country). Many of the Hungarian refugees arrived by bus or on ferries to Malmö, and about 700 settled in the city. ${ }^{37}$ In the following years, about 50-6o Hungarians, both men and women, were employed in MAB \& MYA, with some of them living in temporary housing organised by the company. ${ }^{38}$

The municipality mostly abstained from involvement in the lives of both labour migrants and refugees. Hence, the local industry, in collaboration with national labour market institutions, such as the AMs, continued to be the main actor in local migrant reception in Malmö all through the 195os and into the 1960 , but as the number of migrants decreased the issue became less pressing. As in the case of Estonian war refugees, Hungarian refugees were recoded as potential labourers, and the Social Democratic minister of refugee issues, Ulla Lindström, claimed that the greatest gift Sweden could give a refugee was employment. ${ }^{39}$

35 Sou 1956:53a, Balanserad expansion, Betänkande avgivet av 1955 års långtidsutredning (Stockholm 1956) 26-29; SCB, 'Befolkningsutveckling-födda, döda, in- och utvandring samt giftermål och skilsmässor 1749-2019', chart scb.se (accessed 27 August 2020).

36 Swedner, Invandrarna i Malmö, 51, 303.

37 Swedner, Invandrare i Malmö, 51; A. Svensson Wigerfelt, Ungrare i folkhemmet. Svensk flyktingpolitik i det kalla krigets skugga (Lund 1992), 145.

38 MSA, МАВ \& MYA, Övriga personalhandlingar 1945-1959, FiD:2, 'Sammanställning över utländska arbetare, anställda vid МАВ och MYAs fabriker vid utgången av period 11', 4 December 1957 .

39 Svensson, Ungrare ifolkhemmet. 114. 
A minor proportion of the Hungarian migrants arriving in Sweden were deemed 'problematic' in the eyes of Swedish authorities such as the AMs, especially young men who were unwilling to accept the work offered to them. ${ }^{40}$ In Malmö, Hungarian youth was also deemed problematic and in 1959, the Malmö municipality assigned a budget for youth activities for them.

There are at the moment 500 Hungarian refugee youths up to age 25, and they have severe adjustment difficulties. Representatives of the Hungarian youth have asked the City Council and later the Youth Committee with a request for help to obtain a clubhouse, where the youth through education activities and leisure activities as well as counsellor activities could spend some of their leisure time. ${ }^{41}$

The municipality agreed to help the young Hungarian migrants to find suitable premises and to sponsor some of the rent but did not fund other activities. Hence, the city was in this case active, but not to any large extent. The overall policy of the municipality did not change and it largely abstained from involvement. The shortage of labour was deemed less pressing and the industry was less active in migrant reception but was still the main actor because both labour migrants and refugees were coded as solutions to the labour problem and hence were the responsibility of the industry. The role of the municipality started to change from the mid-196os, as the number of migrants rose, and migrants themselves increasingly became perceived as a 'problem'.

\section{The Municipality's Immigrant Adaptation Policy 1965-1970}

Once Sweden had removed its visa requirements vis-à-vis Yugoslavia, Yugoslav citizens became the largest group of migrants in Malmö in $1965 .{ }^{42}$ At that time, economic recession made it harder to obtain employment in Sweden than before. Furthermore, both Yugoslav and Swedish authorities had boosted expectations about how easy and quick it would be to obtain a work-permit. One consequence of this was that some of the migrants from Yugoslavia arrived with too little money to sustain themselves while waiting for the bureaucracy. ${ }^{43}$

\footnotetext{
40 Svensson, Ungrare ifolkhemmet, 178-205.

41 MSA, DM, AI, Protokoll 16 November 1959, Ärende 636c.

42 Swedner, Invandrarna i Malmö, 67.

43 Byström and Frohnert, Invandringens historia, 40-41.
} 
The well-being of these migrants became the responsibility of the municipality and its Social Service Department.

This situation was repeated in cities all over Sweden. It coincided with the emergence of the so-called 'immigrant question' in public and political debate. When first publicly debated in the 1950s, Sweden's ability to attract labour migrants had been taken as a sign of national success. In the 1960s, it was not so much the migration as the migrants themselves who became the focus of attention. The public debater David Schwarz-himself from a migratory background - was the leader among those who created awareness of the social inequalities hurting some migrant and minority communities, while also proposing multiculturalist policies, foreshadowing the emergence of what Michael Alexander would consider a post-modern and pluralist local attitude. ${ }^{44}$

As discussed in other sections of this special issue, Alexander broadly divides the general approach of European cities to migrants into 'modernist', which comprehends the migrants as a temporary phenomenon and spatially separable, and 'post-modernist', which sees migrants as something permanent and pervasive. The modernist pole is further subdivided into three subsets of attitudes and migrant policies: 'non-policy', 'guest-worker policy' and 'assimilationist policy'. For the period 1945 to 1964, Malmö and Sweden are best described by the 'non-policy' set of attitudes. The post-modernist pole is connected to a set of migrant reception policies summarised as 'pluralist policy'.5 In Alexander's analysis, these policy clusters are connected to phases, which are not the same in every city but have a general trend towards different versions of the modernist approach in the earlier part of the investigated period, with the post-modernist approaches only starting to be represented around 1970. Hence, compared to the cities in Alexander's article, Malmö is firmly committed to the 'non-policy' position in the first and second periods described here, pushing almost all decisions onto industry and other actors. When Malmö and Sweden initiated a debate on migrant reception in 1965 they quickly moved towards a post-modernist phase. In this year, the Swedish government started to develop a migrant reception policy as an extension of the policy developed after the end of the Second World War. The appointment of the Government's Working Party on Immigration was part of this process.

44 D. Schwarz (ed.) Svenska minoriteter. En handbok som kartlägger invandringspolitiken och befolkningsminoriteternas ställning inom det svenska samhället (Stockholm 1966); M. Alexander, 'Local Policies Towards Migrants as an Expression of Host-Stranger Relations. A proposed typology', Journal of Ethnic and Migration Studies 29 (2003) 411-430; Byström and Frohnert, Invandringens historia, 42-44.

Alexander, Local policies, 411-430. 
'Immigrants' adaptation' became a key phrase within these debates and policy-processes, even though it was contentious and instilled with different meanings. ${ }^{46}$

A local version of the immigrant question evolved in Malmö as local actors grappled to figure out their responsibilities for labour migrants without work-permits. In Malmö, these debates tended to focus on migrants from Yugoslavia, who were perceived as different from the labour migrants who had arrived earlier and as being more culturally distant from Swedes. Debate articles in the Social Democrat newspaper Arbetet tended to stress labour migrants' vulnerability, as well as the need to develop a national structure for reception in order to relieve the municipalities from unwarranted responsibilities vis-à-vis migrants who arrived without work-permits, with little money, but with high expectations for job opportunities. ${ }^{47}$ Greta Behring-Andersson, for one, warned about the ongoing formation of 'a proletariat of Yugoslavs'.

There is a proletariat forming in Malmö, consisting of migrating Yugoslavs and others, arriving with a one-way ticket and insufficient start-up capital, no language knowledge and without having applied for a work permit in advance. ${ }^{48}$

Sydsvenska Dagbladet — which until 1966 was aligned with the right-wing party Högerpartiet and then became independently liberal-depicted Yugoslavs as being struck by a 'Sweden Fever'49 An editorial comment on the Social Democratic minister Olof Palme's (later Swedish Prime Minister, 1969-1976 and 1982-1986) Christmas speech of 1965 - in which he focused on immigrants' situation in Sweden and on the need to counter prejudices against immigrants among the majority population-stresses the authorities' responsibility to assure labour migrants the same benefits as citizens, including the right to full pension benefits. ${ }^{50}$ While this news story and the editorial give similar views on labour migrants as the articles in Arbetet, Sydsvenska Dagbladet also connects the Yugoslav citizens in Malmö with criminality and violence, such as the

46 Hansen, Jämlikhet och valfrihet; Dahlström, Nästan välkomna; Mörkenstam, 'Ekonomi, kultur och jämlikhet; Borevi, 'Sverige. Mångkulturalismens flaggskepp i Norden'.

L. Genell-Harrie, 'Ta emot nykomlingar', Arbetet 4 February 1965; G. Behring-Andersson, 'Utländska arbetssökande tas emot med armbågen', Arbetet 18 August 1965; L-O Borglid, 'En klibbig massa av hat', Arbetet 8 March 1966; L-O Borglid, 'Olösta problem', Arbetet 10 March 1966.

48 Behring-Andersson, 'Utländska arbetssökande tas emot med armbågen'.

49 H. Widing, 'Biljetterna var nitlotter', sDS 25 January 1966.

50 'Invandrarnas ställning' sDs 30 December 1965. 
bombing of the Yugoslav embassy in Copenhagen in January 1966 when there was speculations, but no evidence, of connections between the perpetrators and Yugoslav migrants in Malmö. ${ }^{51}$

Between 1965 and 1967, actors within Malmö's municipality tried different approaches as they went through a process of shaping their understanding of the situation into a manageable problem. In 1965, Malmö's Social Service Department stated that it had been a year of heavy costs for social assistance to labour migrants without work-permits. The department reasoned that without help from the national government, very little of its funding would be left for the social assistance of the people of Malmö. The Social Service Department perceived itself to be 'facing a crisis that we cannot control.52 In 1966, Malmö's municipality and the Government's Working Party on Immigration co-hosted a conference, which put politicians and municipal officials in contact with teachers operating an introductory course in Swedish for immigrants, hosted by the popular adult education association Folkuniversitet. ${ }^{53}$ In response to their students' questions and needs, these teachers had developed a voluntary community information programme. At the beginning of 1967, two Social Democrat members of the City Council motioned that the municipality would develop a similar programme for aiding immigrants' adaptation. In their comments on the motion, Malmö's Social Welfare Committee contradicted the statement made by its department two years before, claiming that:

$[\mathrm{S}]$ ocial assistance is provided in very small amounts in individual cases. The often-stated suggestion that foreign citizens more or less often exploit Swedish social benefits is grossly inaccurate. ${ }^{54}$

The City Council approved the motion and assigned the Social Welfare Committee to prepare the municipality's immigrant adaptation programme. First, this involved reshaping the problematisation of immigrants' adaptation as something that could be acted on and handled by the municipal authorities. The most elaborate shaping of this problematisation is found in the report Yugoslavs in Malmö, which was commissioned by the Social Welfare Committee and written by sociologist Kristina Belfrage. .5

$51 \quad$ 'Attentat mot dansk jugoslavambassad. Bomb kan vara av svenskt ursprung' sDs 23 January 1965.

$5^{2}$ Quoted in Järtelius, Bortastaden, 41.

53 Järtelius, Bortastaden, 42, 55-56.

54 Quoted in Järtelius, Bortastaden, 42.

55 K. Belfrage, Jugoslaver i Malmö (Malmö, 1967). 


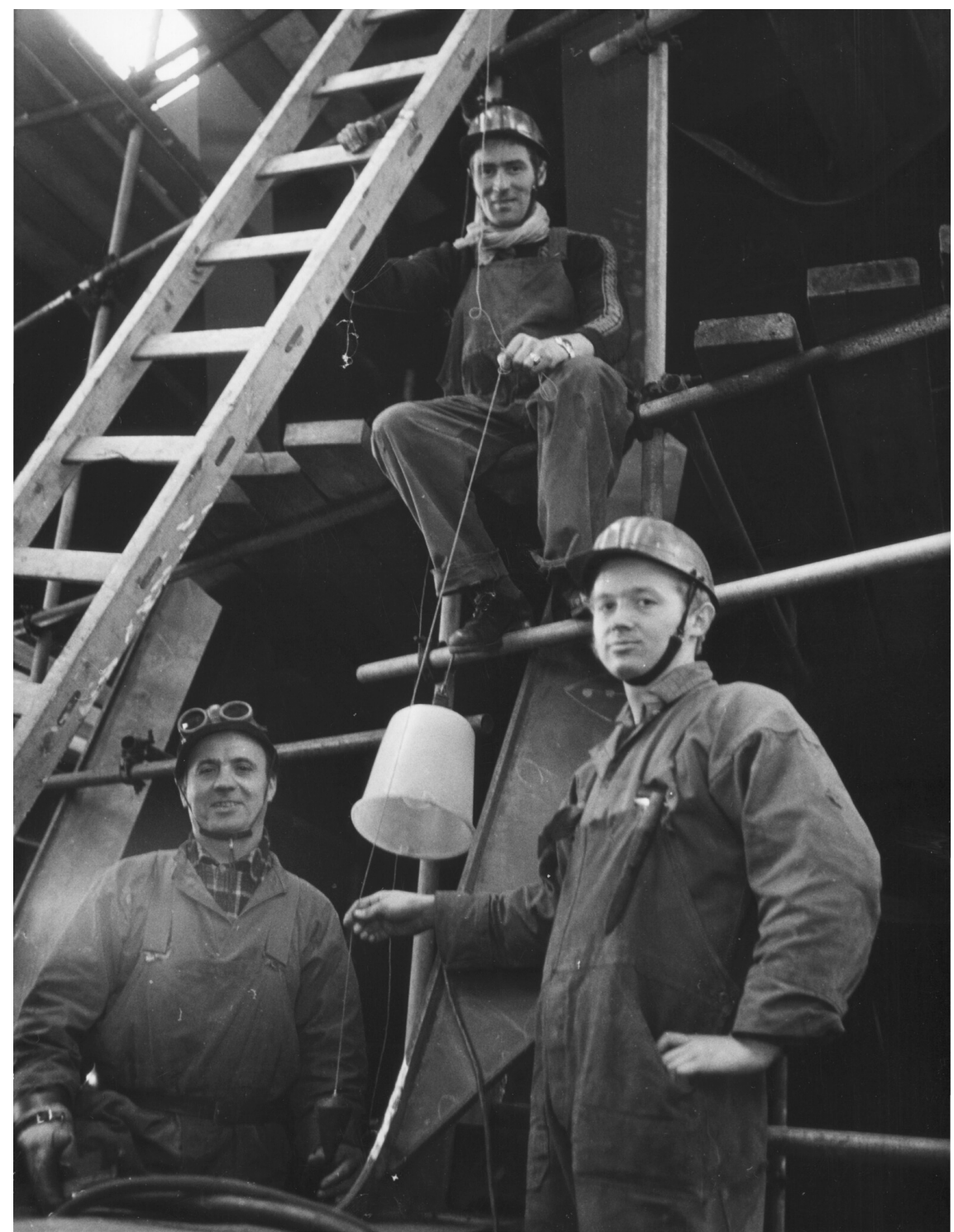

ILLUSTRATION 4 Workers at Kockums shipyard came from a number of countries.

Sitting on the scaffolding is Atilijo Vojskovic from Yugoslavia, standing to the left is Eyiolfur Gunnlaugsson from Iceland and to the right LarsGunnar Sjöö from Sweden. PHOTO: MALMÖ CITY ARCHIVES. 
This report discusses the living conditions and experiences of Yugoslav citizens residing in Malmö (and a control group of Swedish citizens who had recently moved to the city) in relation to ideas about a general process of adaptation, which it was assumed, every immigrant group underwent. Even though it is a keyword in the report's problem description, 'adaptation' is used without definition. The word is however concretised by the formulation of the report's purpose, which is to 'shed light on the Yugoslavian immigrant group's housing conditions and contacts with societal institutions in Malmö'. Meanwhile, the introduction of a second purpose obscures the term once more, since the report also aims to 'shed light on the general adaptation of this group' ${ }^{56}$ By combining discrete observations with a general idea about a migrant group's transit from being newcomers to being part of the receiving society, the report shaped migrant reception as a problem that could be managed by the municipality working as an agent of the wider welfare state.

The first conceptualisation that can be discerned in Belfrage's representation of the problems of Yugoslav citizens in Malmö moves along the lines of social vulnerability and exploitation. Belfrage reports a huge income gap between the Yugoslavs surveyed and the Swedes, while in contrast to the Swedish control group, many of the Yugoslavian migrants worked below their educational qualifications. The report shows that the Yugoslavs residing in Malmö were either doing manual labour or working in service occupations. The migrants from Yugoslavia were also reported as being exploited in the housing sector. The vast majority of them were living in small apartments, with neither central heating nor toilets, rented from private landlords in building stock intended to be demolished. ${ }^{57}$ Belfrage concludes that:

Prejudice can easily arise among the host population if the Yugoslav group will continue to consist of workers in low-wage groups, that also [---] are living in bad housing in separate parts of the town. These are the conditions that the Yugoslav group in Malmö currently is living under. ${ }^{58}$

Belfrage's focus on the social inequalities that the Yugoslavs were exposed to is consistent with a contemporary focus on lasting injustices in the welfare state. She rebuts the idea that migrants from Yugoslavia over-utilised the social security system by showing that those migrants sought social assistance to a lesser degree than the Swedish control group and probably less often than they were

56 Belfrage, Jugoslaver i Malmö, 1-2 (quotes from p. 2).

57 Belfrage, Jugoslaver i Malmö, 8-11, 17-21.

$5^{8}$ Belfrage, Jugoslaver i Malmö, 10. 
entitled to. The report represents the problem as being more about migrants from Yugoslavia not knowing which institution to turn to for their various needs. This lack of knowledge, which is described as a barrier to the Yugoslav group's adaptation, is connected to what is perceived as a generally low mastery of the Swedish language within the Yugoslav group. The report however notes an interest in learning Swedish among the Yugoslavs, and that those few who had been part of popular adult education classes had succeeded especially well. ${ }^{99}$ Thus, Belfrage connects the vulnerability of migrants from Yugoslavia to their not understanding Swedish and being distant from Swedish society.

At some points, the report includes speculations about ethnic differences between Yugoslavs and Swedes. One example is the interpretation of the finding that the Yugoslav group consisted mainly of men, while the Yugoslav women present in Malmö were wage earning to a larger extent than Swedish women:

The difference is interesting - the Yugoslav women are not emancipated enough to migrate here on their own, but after they have arrived they become wage workers. ${ }^{60}$

This interpretation resonates with scholarship on discourses about immigrant women, whom Swedish public discourses and policies have recurrently depicted as being in need of liberation from the cultural values of their old homelands. ${ }^{61}$

As noted above, Yugoslavs' poor standard of housing was represented as problematic, but the fact that this population was concentrated in certain parts of town was depicted as an equal part of the problem since it could give the group a bad reputation among the Swedish population. Further, Yugoslavs seemed to mainly socialise within their own community instead of mixing with Swedes. Hence, the Yugoslav group was racialised as carrying a culture with negative connotations, and it would be better if they left it or mixed it with 'Swedish' culture.

59 Belfrage, Jugoslaver i Malmö, 12-16, 24-31.

6 o Belfrage, Jugoslaver i Malmö, 9 .

61 S. R. Farris, In the name of women's rights. The rise of femonationalism (Durham 2017); M. T. Tureby and J. Johansson, Migration och kulturarv: Insamlingsprocesser och berättelser om och med de invandrade ca 1970-2019 (Lund 2020) 44-45. 


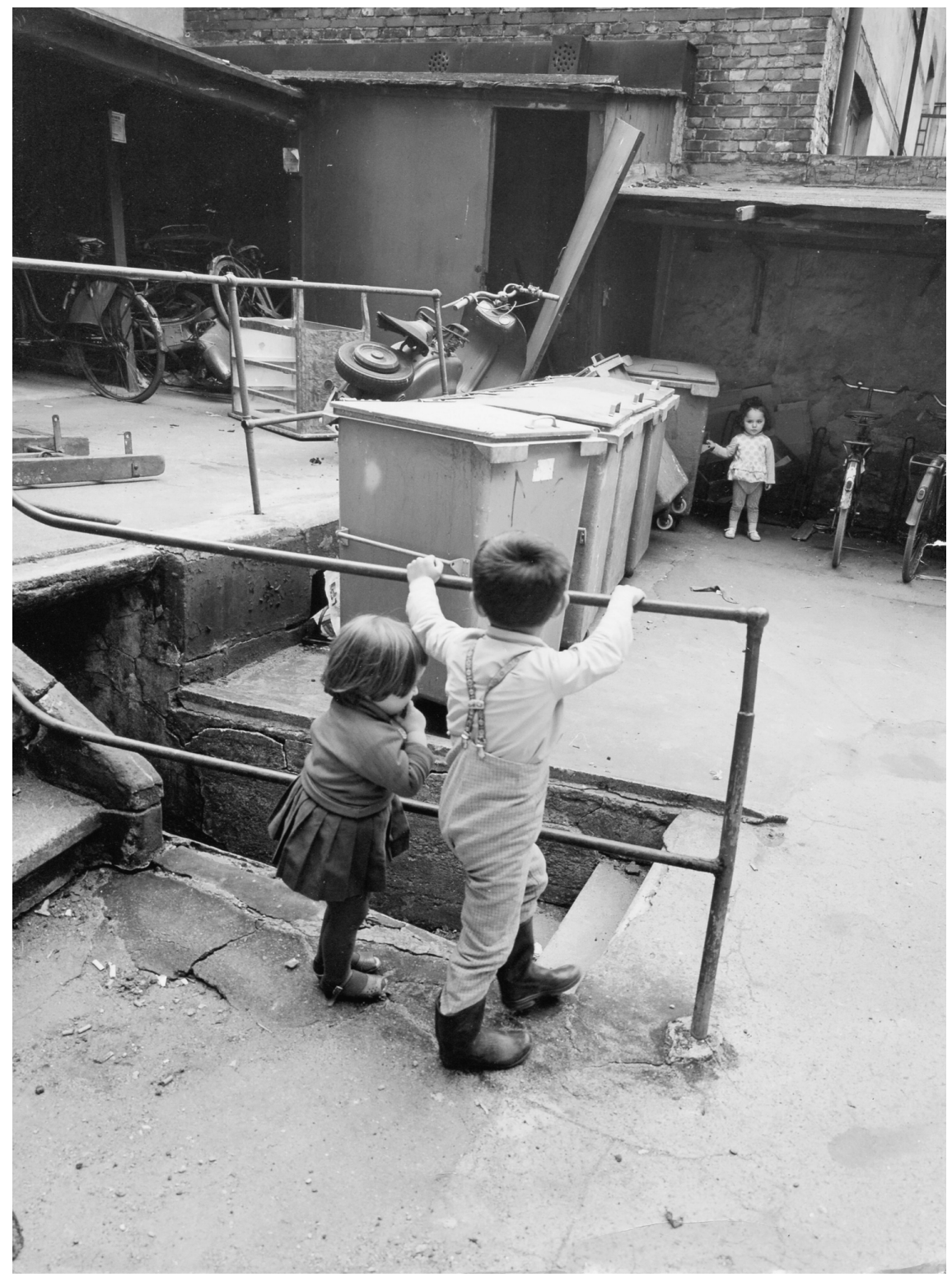

ILLUSTRATION 5 Children of Yugoslav families, residing in unsanitary housing in rundown districts in the centre of Malmö.

PHOTO: BILDER I SYD. 
Meanwhile, Belfrage shows that Swedes were more prone to express suspicion towards foreigners and to maintain their distance from newcomers than Yugoslavs were towards Swedes. According to Belfrage, Yugoslav migrants were what she-in curious resemblance to Behring-Andersen's phrasing in Arbetet two years prior-labels 'the new proletarian class in Sweden'.

That these Yugoslavs feel inhibited, put aside, or inferior, could be because they, as we previously have seen, have reasons to view themselves as the new proletarian class in the Swedish society. They get worse jobs, poorer housing, lower wages than most of us. Even if there are explanations, e.g. language barriers, lack of vocational training and so on, this is unfortunate, since it might be a step in a process of segregation. ${ }^{62}$

Hence, Belfrage was noticing different forms of institutional discrimination and racism in the labour market and in housing. These are not theorised as such, but very much in line with Robert Miles later theorisations. Miles' discussion on racism underscores that racialisation can take the form of explicit doctrinal racism, such as racist slurs and open discrimination, or as institutional racism, which is not articulated but is visible as consequences statistically identifiable as under- or over-representation in specific positions in the labour market, in places of residence or in police interventions. ${ }^{63}$ This was what Belfrage saw happening in Malmö.

Even though it is a central concept in Belfrage's report on the problematisation operating in the migrant reception policy developed by the municipality of Malmö during 1967, 'adaptation' is used in a non-defined, and common-sense way. The questions posed in the survey, as well as the interpretations of the results, give the impression that different conceptualisations of 'immigrants' adaptation' are at work in the report and in the problematisation it offers. On the one hand, adaptation is used to emphasise the agency of migrants in their creation of a life and livelihood in Sweden: it marks their adjustment to new circumstances. On the other hand, the use of the concept seems to promise that the authorities will make sure that migrants will be naturalised, that is, they will become adapted to the ways of living in Sweden. It might be the composite nature of this term that made it so useful for problematising the reception of migrants as it seemed to calm very different anxieties. In relation to the anxiety that migrants without work-permits would constitute a

62 Belfrage, Jugoslaver i Malmö, 5 o.

63 Miles, Racism, 67. 
new proletarian class in a society whose ideological self-construction was to have overcome a class-based society, the report represents immigration as a delimited social problem that could be reformed away. Meanwhile, what was unique about the social vulnerability of migrants-in contrast to other contemporary social problems - was that distance from Swedes and Swedishness was construed as being part of the problem. Not only did the report perceive migrants to lack Swedishness, but it also represented the arrival and presence of migrants as connected to a potential loss of Swedishness. The report warned against ethnic ghettoisation, that is against the situation in which certain city areas become deprived of their Swedishness. It also issued a warning that migration could usher in racial dynamics that were alien to Swedish society and culture up until then, since the presence of migrants could incite racist sentiments in the population. ${ }^{64}$

All in all, Belfrage's report problematised immigrants' adaptation as being a circumstance that required urgent response and yet clearly could be handled by the municipality. The municipality accepted the problematisation offered by Belfrage's report and institutionalised a special municipal office for Immigrant Services. The basis for this office was the community information programme developed at Folkuniversitet but with additional resources and personnel. The principal in charge of the Swedish course also became the director of the municipality's Immigrant Service office.

The problematisation put forward by the report Yugoslavs in Malmö was mostly well received by the local public. The representation of 'the problem' was however challenged by some voices. A commentator for Sydsvenska Dagbladet challenged the municipality's immigrants' adaptation program by casting doubts on Belfrage's report. This commentator depicted the report as being too political and also questioned the representation of migrants as structurally subordinated:

A report as the one commented above does not facilitate the adaptation of migrants, especially not as it is presented in the press and media with claims of foreigners being discriminated. The public has a right to

64 For analyses of Swedish society's refusal to address its racialised social structure, see P. de los Reyes, I. Molina \& D. Mulinari (eds.), Maktens (o)lika förklädnader: Kön, klass \& etnicitet i det postkoloniala Sverige (Stockholm, 2002); P. Gilroy, 'Foreword', in: Michael McEachrane (ed.), Afro-Nordic Landscapes: Equality and Race in Northern Europe (New York \& London 2014); L. Brännström, 'Ras" i efterkrigstidens Sverige: Ett bidrag till en mothistoria', in: T. Hübinette and Andréaz Wasniowski (eds.), Studier om rasism. Tvärvetenskapliga perspektiv på ras, vithet och diskriminering (Malmö 2018). 
demand facts and not biased reports. The understanding between different national communities is best served by factual information. ${ }^{65}$

This commentator clearly tried to push the meaning of adaptation closer to an understanding of the phrase where it meant doing less for and demanding more of migrants. This illustrates the discursive field for which Belfrage's report — and the problematisation it offered the municipality — was produced. The city's policy could be characterised as a balancing between what Alexander defines as the modern and postmodern approaches. Even though it emphasises migrants' capability to fashion their own lives in Sweden, the assimilationist aim is not out of the picture, but is rather assumed to be the endpoint of any successful 'adaptation'. The problematisation allowed for a spectrum of interpretations and interventions, which different actors would try to emphasise differently and hence using the same phrase but with different meanings.

With the report the municipality of Malmö acquired expert knowledge on immigrants' adaptation before the national government did so. It was not until 1968 that the government appointed its own commission on immigration. This commission would make the report Yugoslavs in Malmö part of its own work. ${ }^{66}$

Hence, the main 'problem' relevant for local migration policy changed from a lack of labour to the migrants themselves and how their 'adaption' to Swedish society could be organised. While the former problem-and subsequent problems arising with housing provision etc. - was the responsibility of the industry, the latter transformed migrant reception into a municipal project of societal inclusion.

\section{Conclusion}

The purpose of this article is to describe and analyse by whom, in what ways and with what consequences migrant reception was performed in Malmö during the period $1945^{-1970}$ and how this changed during this time. Our investigation has illustrated that the end of the Second World War marked a shift in migrant policy. The period $1945^{-5}$ o was characterised by labour shortage being perceived as a pressing problem by local industry, which was addressed by recruiting an increased number of labour migrants (and refugees). The increased migration was met by a non-policy response from the municipality

65 S. Ulfstand, 'Utredning om utländsk arbetskraft', SDS 29 January 1968.

66 Belfrage's report is the basis for one of the chapters in Swedner's Invandrarna i Malmö, which was written as a sub-report to the Government's The Commission on Immigration. 
of Malmö, which largely refrained from any involvement in migrant reception. Since the lack of labour in industry was identified as a major problem, migrants were seen as the solution to this, and the municipality found it easy to push the responsibility for migrant reception onto the employing companies. Through a series of connected problematisations, the companies assumed an expanded responsibility for migrant reception. The WPR approach helps us understand this process, pointing out that the way the problem is conceptualised also explains how it is solved. In connection with a labour dispute, the Italian workers were racialised as 'mentally different' and stigmatised.

In the period 1951-1964, labour shortages were less of a problem, which is why only minor groups of migrants arrived. With some minor anomalies, the municipality continued to refrain from active involvement in migrant reception. As the 'problematisations' continued to focus on labour supply, the companies maintained their role as the most important actors in migrant reception in a period when far fewer migrants were arriving.

With a shift in 1964, migrant reception was for the first time created as a problem which the city government should solve, and the municipality took a far more active role in migrant reception, acceding to the 'assimilationist policy' of Alexander's typology with some aspects pointing towards a post-modern pluralist stance. Hence, there was change over time, in line with Alexander's discussion on the phases of migrant reception policies. However, the Malmö case stands out as an example of a very rapid transition, moving as it did over a couple of years from a non-policy to a policy with elements of the postmodern pluralist approach. In comparison with migrant policy development in Sweden in general, Malmö stands out as a forerunner, and the Belfrage report is incorporated into later policy development reports at the national level. Hence, Malmö, as a case, indicates the possibility of the local level informing the national level and underscores the importance of analysing the interconnectivity of different levels in understanding policy development. Our findings therefore confirm the point made by Sarstrand Marekovic about the importance of institutional developments on the local level, and contributes to a more nuanced understanding of the multilevel policy development in this period. ${ }^{67}$

We can also see that migrants were racialised in very different ways: Italian workers were attributed with a 'mentality' that differentiated them from Swedes, Yugoslav women were being perceived as part of a of a culture that oppressed women and Yugoslavs in general were considered to be hampered

67 Marekovic, Från invandrarbyrå till flyktingmottagning. 
by their lack of Swedishness. Estonian women, on the other hand, were racialised as 'white', and we find no evidence of them being subjected to racism. The different migrant groups were racialised in different ways, depending on how they were depicted by Swedish society. We can also see a gendered racialisation as women and men were racialised differently-Italian men as much more of a problem than Estonian women, and Yugoslav women as victims of their own culture-underscoring the term 'racialisation' as a useful tool for a nuanced understanding of the processes of migrant reception.

\section{Acknowledgements}

Master students Sara Hultqvist and Emma Hultqvist have greatly contributed to this article with research in archives and newspapers as well as analysis. The article is part of the project 'Immigrant integration programs in European Cities from the mid 1940s to the 1970s. A comparative case study' funded by Jan Wallanders och Tom Hedelius stiftelse (P17-0021). 